\title{
Problemy ustrojowe i prawne na Rusi Halickiej w granicach Królestwa Polskiego do 1569 roku
}

\section{Uwagi o pracy Igora Bojki Organy władzy i prawo na Rusi Halickiej w sktadzie Królestwa Polskiego (1349-1569) ${ }^{1}$}

W dziejach stosunków wewnętrznych na Rusi Halickiej w czasie jej przynależności do Królestwa Polskiego, nawet ograniczonych chronologicznie do 1569 r., zawiera się ogromna liczba różnorodnych zagadnień, zwykle niezbadanych, z których większość dotyka spraw ustrojowych i panującego tam systemu prawnego. Wszystkie te problemy porusza niedawno powstała praca Органи влади і право в Галичині у складі Польського Королівства (1349$1569 \mathrm{pp}.)^{2}$ autorstwa Igora Bojki, aspirująca do monograficznego i syntetyzującego ujęcia procesu przemian w ustroju i systemie prawnym Rusi Halickiej od momentu jej zajęcia przez Kazimierza Wielkiego do zawarcia unii lubelskiej. Autor wychodzi niejednokrotnie, i to w sposób dość chaotyczny, poza zakreślony wyżej temat. W artykule niniejszym postanowiłem więc skupić się tylko na kilku wybranych zagadnieniach poruszanych w pracy Bojki, które wymagają niezbędnego komentarza. Są to głównie problemy związane z kluczowymi przemianami ustrojowymi na Rusi Halickiej, jak wprowadzenie i funkcjonowanie urzędu starosty oraz status prawny warstw bojarów i ich własności (praw do ziemi). Kompetentnym historykom prawa należy pozostawić dyskusję nad obszernymi partiami tej książki dotyczącymi problematyki ściśle prawnej.

Autor monografii jest lwowskim badaczem młodego pokolenia o bardzo szerokich zainteresowaniach naukowych z zakresu historii ustroju i prawa na ziemiach Ukrainy XII-XIX w. oraz o imponującym dorobku z tej dziedziny. Jest autorem m.in. podręcznika akademickiego do historii państwa i prawa

${ }^{1}$ I. Бойко, Органи влади і право в Галичині у складі Польського Королівства (1349-1569 рр.). Монографія, Львів 2009.

${ }^{2}$ Pojęcie Hałyczyna (Галичина) w tej recenzji tłumaczę jako „Ruś Halicka” lub „Ruś Czerwona", co jest zgodne z terminologią przyjętą w polskiej historiografii. 
Ukrainy Hetmańskiej, wykładów z historii ustroju i prawa Rusi Kijowskiej, współautorem monografii Państwa Halicko-Wołyńskiego (1199-1349) oraz ponad 80 innych prac, artykułów i abstraktów ${ }^{3}$.

Za cel omawianej pracy postawił sobie I. Bojko zbadanie procesu formowania i funkcjonowania systemu prawno-administracyjnego Rusi Czerwonej w początkowym jej okresie przynależności do Królestwa Polskiego, czyli do 1569 r. (s. 3) i wyraził nadzieję, że badania nad organizacją władzy pozwolą stworzyć model instytucji prawno-państwowych (s. 7). Odpowiedzi na pytanie o wspólne z innymi krajami Europy korzenie ukraińskiego systemu i kultury prawnej autor szuka w ukraińskiej tradycji państwowej i prawie (s. 4) ${ }^{4}$. Podkreśla też potrzebę reinterpretacji niektórych faktów historycznych. W pracy szczególnie cenne jest szerokie zestawienie literatury, zarówno ukraińskiej i rosyjskiej, jak i polskiej: historycznoprawnej i historycznej, zwłaszcza zaś wykorzystanie różnych podręczników historii prawa, co pozwala na przegląd ich treści pod kątem omawianego zagadnienia. Istotną zaletą jest także sam fakt podjęcia tej ze wszech miar trudnej i skomplikowanej tematyki. Niewątpliwie ambitnie pomyślana i prekursorska książka, mimo swych niedoskonałości, zasługuje na docenienie rozpiętość omawianych zagadnień, jak i ich umocowanie pomiędzy dwiema dyscyplinami naukowymi, które nadal w zbyt małym stopniu wykorzystują wzajemnie własne osiągnięcia badawcze. Uświadamia ona bowiem rozmiar potrzeb w zakresie badań szczegółowych nad wieloma zagadnieniami, a także konieczność uzgodnienia choćby wspólnych kategorii analizy rzeczywistości historycznej, jeszcze odmiennych zarówno w wymiarze metodologicznym, światopoglądowym, a nawet ideologicznym i politycznym.

Fakt podjęcia się przez autora tak ambitnego zadania, jakim jest synteza dziejów ustroju i prawa na Rusi Halickiej w latach 1349-1359, zasługuje więc na uznanie. Wiele zagadnień autor przedstawił rzetelnie i spójnie, co wiąże się być może z jego zainteresowaniami badawczymi. Szczególnie imponujące są fragmenty dotyczące samorządu ormiańskiego na Rusi Halickiej oraz części poświęcone analizie statusu jej najniższych warstw społecznych.

Aby ukazać szeroki wachlarz poruszanych przez autora problemów, warto pokrótce przedstawić strukturę pracy. Najpierw omawia on polityczne i praw-

${ }^{3}$ I. Бойко, Держава і право Гетьманщини, Львів 2000; idem, Державний лад і право Київсккої Русі, Львів 2004; idem, Галииько-Волинська держава (1199-1349 рр.), Львів 2006; cyt. za: http://law.lnu.edu.ua/departments/history-of-state/staff/boiko-igor-iosipovich/

${ }^{4}$ Autor używa terminów: „Ukraińcy”, „ludność ukraińska”, „ludność halicka” w odniesieniu do autochtonicznej prawosławnej ludności używającej języka ruskiego i zamieszkującej obszar Rusi Halickiej w średniowieczu. Są to terminy obiektywnie anachroniczne i obce polskiej historiografii, w której na określenie tej ludności zawsze funkcjonował źródłowy i współczesny termin „Rusini” (łac. Rutheni), którym posługuję się także w tej recenzji. Podkreślam jednak, że akceptuję tę umowną terminologię, którą posługuje się historiografia ukraińska, por. L. Kolankowski, Kilka uwag o Prof. M. Hruszewskiego Historyi Ukrainy-Rusi, t. IV-VI, Lwów 1913, s. 3. 
ne aspekty przyłączenia Rusi Halickiej do Królestwa Polskiego, wchodząc przy tym głęboko w zagadnienia z dziedziny historii politycznej i społecznej Rusi i Polski, a - chronologicznie - sięgając od wczesnego średniowiecza. Następnie przedstawia system organów władzy publicznej na Rusi Halickiej, zarówno centralnych jak i miejscowych oraz organy samorządu lokalnego wszystkich stanów i grup społecznych. W ostatnim zaś rozdziale omawia jej prawo, poczynając od źródeł prawa na Rusi i nawiązując głęboko do systemu prawnego Korony oraz charakteryzując poszczególne dziedziny (prawo cywilne, karne i procesowe) i instytucje prawa.

Autor szeroko wykorzystał badania historyczne i historycznoprawne zarówno ukraińskie, jak i rosyjskie. Również dorobek polskich badaczy uwzględnił w dość szerokim zakresie, zwłaszcza starszą literaturę historyczną i historycznoprawną, a także nowsze publikacje historycznoprawne. Jednak pewne zastrzeżenia budzi pominięcie najnowszego dorobku polskich historyków. Szczególnie rażące jest niewykorzystanie żadnej z wielu prac Janusza $\mathrm{Kurtyki}^{5}$, wiele wnoszących do poszczególnych aspektów omawianej problematyki, a także niektórych publikacji Andrzeja Janeczka ${ }^{6}$, Tomasza Jur-

${ }^{5}$ J. Kurtyka, Z dziejów walki szlachty ruskiej o równouprawnienie: represje lat 1426-27 i sejmiki roku 1439, „Roczniki Historyczne”, t. 66: 2000, s. 83-120; idem, Poludniowy odcinek granicy polsko-ruskiej we wczesnym średniowieczu (przed 1340 r.) w świetle źródel historycznych, [w:] Początki sąsiedztwa. Pogranicze etniczne polsko-rusko-stowackie w średniowieczu. Materiały z konferencji-Rzeszów 9-11 V 1995, red. M. Parczewski, Rzeszów 1996, s. 183-204; idem, Osadnictwo średniowieczne. Początki osady i miasta, [w:] Dzieje Rzeszowa, t. 1, red. F. Kiryk, Rzeszów 1994, s. 97-166; idem, Problem klienteli możnowładczej w Polsce późnośredniowiecznej, [w:] Genealogia. Władza i spoleczeństwo w Polsce średniowiecznej, red. A. Radzimiński i J. Wroniszewski, Toruń 1999, s. 47-124; idem, Wstęp, [w:] Urzędnicy podolscy XIV-XVIII wieku. Spisy, Kórnik 1998, s. 7-28; idem, Podole między Polska i Litwa w XIV i pierwszej połowie XV w., [w:] Kamieniec Podolski. Studia z dziejów miasta i regionu, t. 1, red. F. Kiryk, Kraków 2000, s. 9-59; idem, Nadanie starostwa podolskiego Teodorykowi z Buczacza w 1442 roku (z dziejów królewszczyzn na Podolu w XV i XVI wieku), [w:] Annales Academiae Pedagogicae Cracoviensis. Studia Historica III. Księga jubileuszowa profesora Feliksa Kiryka, red. A. Jureczko, F. Leśniak, Z. Noga, Kraków 2004, s. 69-71; idem, Podole między Polska i Litwa w XIV i pierwszej połowie XV w., [w:] Kamieniec Podolski. Studia z dziejów miasta i regionu, t. 1, red. F. Kiryk, Kraków 2000, s. 9-59; idem, Podolia: the „Rotating Borderland” at the Crossroads of Civilizations in the Middle Ages and in the Modern Period, [w:] On the Frontier of Latin Europe, Integration and Segregation in Red Ruthenia 13501600, ed. by T. Wünsch, A. Janeczek, Warsaw 2004, s. 119-188; idem, Enfeoffment and dientship in the late medieval Kingdom of Poland: The case of Red Ruthenia (Rus'), „Questiones Medii Aevii Novae", Vol. 5: 2000, s. 267-278.

${ }^{6}$ A. Janeczek, Polska ekspansja osadnicza w ziemi lwowskiej w XIV-XVI wieku, ,Przegląd Historyczny", t. 69:1978, z. 4, s. 597-622; idem, Exceptis schismaticis. Upośledzenie Rusinów w przywilejach Władystawa Jagietly, „Przegląd Historyczny”, t. 75: 1984, z. 3, s. 527-542; idem, System grodowo-terytorialny Rusi halickiej w źródlach późnego średniowiecza, [w:] Lokalne ośrodki władzy państwowej w XI-XII wieku w Europie Środkowo-Wschodniej, red. S. Moździoch, Wrocław 1993, s. 143-57; idem, Granice a procesy osadnicze: średniowieczna Ruś Halicka w polu interferencji, [w:] Poczatki sasiedztwa. Pogranicze etniczne polsko-rusko-słowackie w średniowieczu. Materiały z konferencji - Rzeszów 9-11 V 1995, red. M. Parczewski, Rzeszów 1996, s. 291-295; idem, Faktorie, powiaty i dwory. Trzy sfery miejskiego ruchu lokacyjnego na Rusi Czerwonej (XIII- 
$\mathrm{ka}^{7}$, Andrzeja Marca ${ }^{8}$ i Macieja Wilamowskiego 9 , a nawet ukraińskich historyków: Jurija Zazuljaka ${ }^{10}$ i Vitalija Michajłowskiego ${ }^{11}$.

Kwestią kolejną jest konstrukcja pracy i sposób przedstawienia treści przez autora. Istotnym mankamentem jest chaos uwidaczniający się $\mathrm{w}$ toku narracji, który utrudnia lekturę. Praca pełna jest powtórzeń i sprzecznych sądów, przemieszania wątków i braku precyzji w opisach. Jako przykład niech posłuży omówienie formowania się i powstawania wewnętrznych podziałów stanu szlacheckiego w Polsce (s. 146): autor pisze o drobnej szlachcie, po czym przechodzi do omawiania formowania się warstwy średnioszlacheckiej, następnie pisze o tym, że szlachta ta sama uprawiała ziemię, gdyż nie miała poddanych. Niestety z treści nie wynika, czy chodzi o szlachtę średnią, o której autor pisał w poprzednim zdaniu, czy o opisywaną wcześniej drobną szlachtę. Możemy się jedynie domyślać, że o tę ostatnią. W tym samym miejscu, przy omawianiu warstwy bojarstwa na Rusi Halickiej (s. 143-149), autor najpierw przedstawia status bojarów na Rusi na początku rządów polskich, następnie genezę szlachty w Polsce i jej stanowisko na Rusi zwłaszcza po

-XV wiek), [w:] Procesy lokacyjne miast w Europie Środkowo-Wschodniej. Materiaty z konferencja w Ladku-Zdroju 28-29 października 2002 r., red. C. Buśko, M. Goliński, B. Krukiewicz, Wrocław 2006, s. 421-445; idem, New authority, new property. The fundation of noble estates in Red Ruthenia during the fourteenth and fifteenth centuries, „Ouestiones Medii Aevi Novae”, Vol. 7: 2002, s. $77-125$.

${ }^{7}$ T. Jurek, Geneza szlachty polskiej, [w:] Šlechta, moc a reprezentace ve středoveku. Colloquia mediaevalia Pragensia 9, Praha 2007, s. 63-140.

${ }^{8}$ A. Marzec, Kariery polityczne na Rusi Czerwonej za panowania Kazimierza Wielkiego (1340-1370), „Соціум. Альманах соціалної історіі”, Вип. 4: 2004, s. 13-14.

${ }^{9}$ M. Wilamowski, Familia dworska Piotra i Andrzeja Odrowązów Sprowskich, wojewodów i starostów ruskich, [w:] Polska i jej sąsiedzi w późnym średniowieczu, red. K. Ożóg i S. Szczur, Kraków 2000, s. 273-322 (ukraińskojęzyczna wersja tego artykułu: idem, Надвірна фаміля Пьотра та Анджея Одрованжів зі Спрові, воевод та старост руськіх, „Молода Нація. Альманах”, R. 2001, no 3, s. 85-148); idem, Magnate Territories in Red Ruthenia in the Fourteenth and Fifteenth Centuries. Origin, Development and Social Impact, [w:] On the Frontier of Latin Europe, Integration and Segregation in Red Ruthenia 1350-1600, ed. by T. Wünsch, A. Janeczek, Warsaw 2004, s. 81-118.

${ }^{10}$ Ю. Зазуляк, Застави як елемент роздавничой політики Яателлонів у Галицький Русі в $X V$ cm., „Вісник Львівського Університету. Серя історічна”, Вип. 35-36, 2000, s. 43-47; idem, Взаємовідносини старост і шляхти в Галицькій Русі пізнього середньовіччя, [w:] Централна i Східна Свропа в XV-XVIII століттях. Пітання сочіално-економічной та політічной історії. До 100-річчя дня народження Професора Дімітра Погілевіча, Львів 1998, s. 75-86; idem, Шляхта на Львівському передмісті в XV cm. (3 історії міжстанових відносин у Галицькиій Русі пізнього середньовіччя), „Вісник Львівського Університету. Серя історічна”, Вип. 37, 2002, s. 86-94.

11 В. Михайловский, Західне Поділля під володінням Вітовта у 1411-1430 роках: надавча політика у світлі документів, [w:] До джерел. Збірник наукових праць на пошану Олега Купчинськохо з находи його 70-річчя, Київ-Львів 2004, s. 110-128; idem, Велика земельна власність на західному Поділлі у XV cm. (на прикладі документів для Шафранців і Одровонжів), [w:] Kamieniec Podolski. Studia z dziejów miasta i regionu, t. 2, red. F. Kiryk, Kraków 2005, s. 90-98; idem, Правління Коріатовічів на Поділлі (1340-ві - 1394 рр.): Сочіальна структура князівського оточення, „Український Історичний Журнал”, 2009, no 5, s. 34-47. 
1434 r., dalej przechodzi do omówienia podziałów wewnątrzstanowych wśród szlachty polskiej, po czym powraca do naświetlania stanowiska tej szlachty na Rusi i form własności ziemskiej, aby po raz kolejny powrócić do omawiania podziałów stanu szlacheckiego, tym razem według statutu wiślickiego. Kilka stron dalej (s. 153- -154) autor po raz kolejny powraca do omawiania statusu prawnego szlachty na Rusi.

W wielu miejscach I. Bojko przedstawia sprzeczne ze sobą sądy. Omawiając wpływ organów władzy państwowej na Ruś, podkreśla autonomię Rusi Halickiej za panowania Kazimierza Wielkiego, stawiając nawet hipotezę o unii personalnej dwóch królestw (s. 216-217) ${ }^{12}$, a jednocześnie pisze o okupacji Rusi przez Kazimierza Wielkiego realizowanej poprzez konfiskaty i za pomocą kolonizacyjnych działań starostów i napływającej z Polski szlachty (s. 218) ${ }^{13}$. Przedstawiając sąd grodzki (s. 239), autor twierdzi, że na Rusi Halickiej w drugiej połowie XIV w. ustanowiono obowiązkowe prowadzenie ksiąg sądowych, po czym w następnym akapicie pisze, zgodnie z prawdą, że obowiązek prowadzenia ksiąg sądowych wprowadzono po $1434 \mathrm{r}$.

Szczególnie uciążliwe dla czytelnika jest unikanie wskazań chronologicznych w narracji. Omawiając proces kształtowania się stanów (s. 142-43), autor nie podaje żadnych sygnalizacyjnych dat, które w tym miejscu są konieczne ze względu na długotrwałość i wielofazowość tego procesu. Kiedy autor omawia kompetencje wojewodów i kasztelanów (s. 226), można odnieść wrażenie, że pisze o czasach, gdy mieli oni szerokie uprawnienia (w Polsce do końca XIII w.), ale funkcjonowali już na Rusi (po 1434 r.). Pisze tam: „na terytorium województwa ruskiego były cztery kasztelanie", a zatem jednak omawia okres po $1434 \mathrm{r}$. To jednak nie przeszkadza mu w następnym zdaniu skonstatować, że wraz z rozszerzeniem immunitetu kasztelanowie utracili większość swych kompetencji, co oczywiście miało w Polsce miejsce na przełomie XIII i XIV w.

Autorowi zdarza się także popadać w uogólnienia i zbytnie uproszczenia w przedstawianiu problemu. Na przykład stwierdza (s. 234), że w 1434 r. skasowano na Rusi Halickiej instytucje prawa ruskiego i zastąpiono je instytucjami polskimi, co jest stwierdzeniem zbyt ogólnikowym i nieprecyzyjnym, gdyż był to proces długotrwały i złożony. Dość wspomnieć, że urząd wojewody grodowego (wojewoda carski) charakterystyczny dla prawa ruskiego

12 Przy omawianiu tego zagadnienia autor oparł się głównie na artykule J. Sieradzkiego, Regnum Russiae. Polityka ruska Kazimierza Wielkiego. Krytyka dotychczasowych pogladów i zarys nowej konstrukcji. (Na marginesie pracy J. Dąbrowskiego „Korona Królestwa Polskiego”), „Kwartalnik Historyczny”, t. 65: 1958, s. 506-507.

${ }^{13}$ Tezy te autor zaczerpnął z: М. Грушевський, Історія Украӥни-Руси. T. IV: XIV-XVI вікі - відносини політичні, [вид. 2 розщирене], Київ-Львів 1907, s. 58, 61-62; T. V: Суспільнополітичний і церковний устрій і відносини в украӥнсько-руських землях XIV-XVII в., Київ-Львів 1905, s. 20-22; T. VI: Житя економічне, культурне, начіональне XIV-XVII віків, Київ-Львів 1907, s. 235-236. 
funkcjonował jeszcze w 1466 r. w Przemyślu, a w 1476 r. w Sanoku ${ }^{14}$, z drugiej zaś strony część instytucji prawa polskiego funkcjonowała na Rusi już na długo przed $1434 \mathrm{r}$.

Problemem, na który należy zwrócić uwagę, jest wykraczanie autora poza temat pracy. Zawiera ona bowiem sporo zbędnych dygresji i fragmentów mających niewiele wspólnego z poruszanym zagadnieniem, przez co książka rozrosła się do rozmiaru niemal 600-stronicowego dzieła. Przykładem jest nawiązanie do wygłaszanych przez polską szlachtę ideologicznych poglądów „o odwiecznych prawach Polski do Rusi wywodzących się jeszcze od czasów Bolesława Chrobrego". Temu zagadnieniu autor poświęca więcej miejsca podczas omawiania unii lubelskiej, prezentując obszerny i wyszczególniony tytułem passus (s. 130-134). Prowadzi w nim dyskusję z tezą o misji Polski na Wschodzie, polemizując z polskimi kronikarzami i historykami poczynając od Galla Anonima, co przypomina nieco wyważanie otwartych drzwi. Autor nie szczędzi przy tym powierzchownych uogólnień i sądów nacechowanych emocjonalnie. Wydaje się, że ciekawa skądinąd kwestia ideologii uzasadniającej ekspansję na Wschód w polskim piśmiennictwie politycznym i społecznym XI-XX w., nie ma nic wspólnego z zagadnieniami omawianymi w monografii i jest odrębnym tematem, który można było omówić w osobnej publikacji ${ }^{15}$. Kolejny wyszczególniony passus tegoż rozdziału poświęcono zawarciu kościelnej unii brzeskiej, jej przyczynom i konsekwencjom (s. 134-140), co również wykracza poza zakres pracy.

Pierwszym spośród kilku zagadnień merytorycznych, które warto omówić bardziej szczegółowo, są stosunki między władcą a bojarstwem halickim po zajęciu Rusi przez Kazimierza Wielkiego. Kwestia ta od zawsze stanowiła punkt sporny między historiografią ukraińską a polską i była przez nie radykalnie odmiennie postrzegana ${ }^{16}$. Autor prezentuje w tej sprawie pogląd zbliżony do tego, który w XIX w. prezentowała historiografia narodnicka,

${ }^{14}$ AGZ XIII, nr 6256; AGZ XVI, nr 1193. We Lwowie w latach 1468-1491 funkcjonował urząd podwojewodziego przedmieścia lwowskiego (podwoyewodzego suburbii castrensi leopoliensi): AGZ XV, nr CCLXII; AGZ XV, nr 708; AGZ XV, nr 2176.

${ }^{15}$ Również w innym miejscu autor polemizuje $\mathrm{z}$ przedwojenną literaturą polską mówiącą o ,polskiej misji” szerzenia i obrony chrześcijaństwa na Wschodzie, twierdząc, że kulturalny rozwój Rusi stał na bardzo wysokim poziomie, co było spowodowane wczesnym przyjęciem chrześcijaństwa i wszechstronnymi kontaktami z Bizancjum i krajami zachodnimi (s. 106-107). Wtóruje tym samym tezom historiografii narodnickiej prezentowanym przez M. Hruszewskiego (М. Грушевський, Історія Украйни-Руси. Т. VI, s. 139-140).

${ }^{16}$ O poglądach historiografii na tę kwestię: A. Janeczek, Polska ekspansja, s. 597; idem, Osadnictwo pogranicza polsko-ruskiego. Województwo betskie od schytku XIV do poczatku XVII w., Wrocław 1991, s. 69-71; idem, New Authority, s. 80-82; R. Trawka, Z dziejów migracji na wschód. Stan i kierunki badań nad szlachta Rusi Czerwonej w póńnym średniowieczu i wczesnej epoce nowożytnej, [w:] Rody na Śląsku, Rusi Czerwonej i w Małopolsce: średniowiecze i czasy nowożytne. Stan badań, metodologia, nowe ustalenia, red. W. Zawitkowska, A. Pobóg-Lenartowicz, Rzeszów 2010, s. 93-101. 
uważająca, że Kazimierz Wielki po zajęciu Rusi dokonał licznych konfiskat i wywłaszczeń ${ }^{17}$. Ukraiński historyk Jurij Zazuljak już 10 lat temu dokonał swego rodzaju ,rozliczenia” $\mathrm{z}$ tym dziejopisarstwem i jasno ukazał jego tendencyjność ${ }^{18}$. Niestety, I. Bojko przebieg tego procesu opisuje w sposób nieco jednostronny (s. 102-103). Zbyt emocjonalnie interpretując fakty, przydaje Kazimierzowi Wielkiemu negatywne cechy bezwzględnego agresora spiskującego z papiestwem w celu zagarnięcia prawosławnych ziem ruskich i wprowadzenia tam katolicyzmu (s. 104-105) ${ }^{19}$. Zgodnie z poglądem autora, po zajęciu Rusi w 1349 r. Kazimierz Wielki musiał bronić swej zdobyczy ze względu na jednoznacznie ,wrogą postawę ludności ruskiej”20, a do złamania tego oporu doszło przez masowe konfiskaty ziemi kniaziów i bojarów, którzy nie pogodzili się z utratą niezależności przez księstwo halickowołyńskie (s. 107-108) ${ }^{21}$. Jednocześnie poprzez intensywną kolonizację król - rzekomo - dążył do przekształcenia prawa i polonizacji ludności ruskiej (s. 114). Żadne ze znanych źródeł nie potwierdza tezy o - jak to autor ujął: „wrogim nastawieniu ludności do polskiej władzy” (s. 107). Już w 1352 r. Otto z Pilicy, starosta generalny Rusi, wspólnie z ruskimi i polskimi ziemianami przeprowadzał rozgraniczenie dóbr w wołości przemyskiej; podobne rozgraniczenie przeprowadził rok później, w asyście całej miejscowej elity bojarskiej $^{22}$. W 1366 r. w czasie wojny z Litwą brak jest wzmianek o rzeko-

${ }^{17}$ М. Грушевський, Історія України-Руси. Т. IV, s. 58, 61-62, Т. V, s. 21, T. VI, s. 235-36.

18 Ю. Зазуляк, Стан та перспективи дослджень над иляхтою в украйнській icmopiozpaфiï, [w:] Genealogia. Stan i perspektywy badań nad społeczeństwem Polski średniowiecznej na tle porównawczym, red. J. Pakulski i J. Wroniszewski, Toruń 2003, s. 333, 337-344. Szczególnie krytycznie wypowiedział się o historiografii okresu radzieckiego, która w dużym stopniu oparła się na tezach historiografii narodnickiej, przejmując zwłaszcza jej antypolskie tony, choć jednocześnie zwalczała ją ze względu na jej nacjonalistyczne cechy sprzeczne z sowiecką ideologią. Autor ten zauważył także, że we współczesnej historiografii ukraińskiej odżywa mit łączący w sobie historiografię narodnicka, derżawnicka i sowiecką (s. 342).

${ }^{19} \mathrm{~W}$ tych poglądach widać, że autor nie odrzuca paradygmatu narodowego (por. przyp. 18), zob. R. Trawka, Z dziejów migracji, s. 97-98, 126-127.

${ }^{20}$ Autor, pisząc o „wrogiej postawie ludności ruskiej” w 1350 r., powołuje się na: Icmopiя Украйнської РСР: у 8 m. T. 1: Первіснообщинний лад і розвиток феодалізму (з найдавніших часів до середини XVII cm.). Кн. 2: Розвиток феодалізму. Наростання антфеодалної боротьби (Друга половина XIII - периа половина XVII cm.), ред. В.О. Голобуцький, С.З. Заремба, Я.Д. Ісаєвич, П. В. Михайлина, Київ 1979, s. 23. Zbliżony pogląd wyraził już М. Грушевський, Iсторія Украӥни-Руси. T. IV, s. 40, 58, T. VI, s. 235-36, twierdząc, że we wschodniej części Rusi Halickiej panowanie polskie było połowiczne, gdyż wszędzie pełno było zagonów tatarskich i oddziałów ruskich, zaś polskie załogi siedziały tylko w grodach.

${ }^{21}$ Autor, powołując się na: Ф.М. Шабульдо, Земли Юго-Западной Руси в составе Великого Княжества Литовского, Киев 1987, s. 50, twierdzi, że w 1366 r. ludność ruska w czasie wojny Polski i Węgier z Litwą stanęła po stronie tej ostatniej. Na stronie 50 cytowanej przez autora pracy brak jest takiej informacji, poza tym przebieg zdarzeń tam przedstawiony dotyczy lat 1349-1352.

${ }_{22}$ Dokument graniczny czerwonoruski z 1352 roku, wyd. A. Prochaska, KH, t. 14:1900, s. 54 = ZDM IV, nr 943; Akt graniczny czerwono-ruski z 1353 r., wyd. A. Prochaska, KH, t. 10: 1896, s. $814-15 .=$ ZDM IV, nr 946. 
mym popieraniu Litwinów przez miejscową ludność (s. 107). Nic nie wiemy też o masowych konfiskatach i wygnaniu bojarów i książąt (s. 108) ${ }^{23}$. Autor nie opatrzył niestety tej tezy przypisem, więc nie wiadomo skąd zaczerpnął tę informację ${ }^{24}$. Nie powołuje się nawet na jedyną istniejącą wzmiankę o konfiskacie wsi Sulimów Waśkowi i Jackowi Butwiczom, przeprowadzonej przed 1360 r. z powodu zdrady i udziału w najazdach litewskich Lubarta ${ }^{25}$. Brak jakichkolwiek innych wzmianek świadczy raczej o wyjątkowości tego typu postaw. Natomiast istnieje wiele informacji o nadaniach czynionych $\mathrm{w}$ tym czasie na rzecz miejscowego bojarstwa. Na ogólną liczbę 21 znanych nam aktów nadawczych, co najmniej 6 zostało wystawionych na rzecz ruskich bojarów ${ }^{26}$. Do tego należy doliczyć 5 potwierdzeń nadań poczynionych niegdyś przez książąt halickich ${ }^{27}$. W czasach Kazimierza Wielkiego źródła odnotowały wiele transakcji handlowych, w których bojarzy ruscy kupowali i sprzedawali swe dobra. Poza tym liczni urzędnicy na Rusi Czerwonej wywodzili się w tym czasie z miejscowego bojarstwa (Michał wojewoda grodowy włodzimierski, Chodko wojewoda grodowy halicki, Piotr Iwanowicz wojewoda grodowy żydaczowski) ${ }^{28}$. Przedstawicieli bojarskich elit stale odnajdujemy w źródłach w otoczeniu starostów i króla. Nie należy zapominać o rodzie Korczaków, których przedstawiciele zrobili w tym czasie w Królestwie oszałamiającą karierę (Chodko, Piotr Żaba i Ostaszko Iwanowicze, Dymitr z Łady i Goraja), jednocześnie posiadając ogromne dobra na Rusi ${ }^{29}$. Widać więc, że

${ }^{23}$ A. Janeczek, Migracje szlachty polskiej na Ruś - w poszukiwaniu awansu społecznego i majątkowego (XIV-XVw.), [w:] Człowiek w średniowieczu. Między biologia a historiq, red. A. Szymczakowa, Łódź 2009, s. 152-153; idem, Udziat szlachty w kolonizacji Rusi Koronnej: migracje rodów i ich nowa własność (XIV-XV w.). Próba ujęcia syntetycznego, [w:] Rody na Śląsku, Rusi Czerwonej i w Małopolsce: średniowiecze i czasy nowożytne. Stan badań, metodologia, nowe ustalenia, red. W. Zawitkowska, A. Pobóg-Lenartowicz, Rzeszów 2010, s. 64.

${ }^{24}$ Jest to być może efekt bezkrytycznego przyjęcia tez dawnej historiografii ukraińskiej i rosyjskiej (М. Грушевський, Історія України-Руси. Т. IV, 58, 61-62; Т. VI, s. 235-36; И.П. Филевич, Борьба Польши и Литвы-Руси за галичко-владимирское наследие. Историческіе очерки, Санкт-Петербург 1890, s. 212-214, które nowsza literatura ukraińska już zweryfikowała (zob. przyp. 18 i 19).

${ }^{25}$ KDM III, nr 739.

${ }^{26}$ KDM III, nr 715; ZDM IV, nr 958; KDM I, nr 252; KDM III, nr 743; KDM III, nr 797; ZDM IV, nr 1005.

${ }^{27}$ AGZ II, nr 1; ZDM IV, nr 958; KDM III, nr 743; AGAD, Metryka Koronna, sygn. 48, s. 822, ed. zob. J. Tęgowski, Okoliczności wstapienia na tron halicko-wołyński Piasta mazowieckiego Bolesława Trojdenowica, „Studia Podlaskie”, t. 18: 2010, Dodatek 2; AGZ I, nr 5.

${ }^{28}$ KDM III, nr 701; S. Barącz, Archiwum domowe, „Towarzysz Duchowieństwa Katolickiego", t. 1: 1864, s. 486-88 = J.A. Spież, Trzy niedocenione czternastowieczne dokumenty z archiwum dominikanów w Żółkwi, [w:] Narodziny Rzeczypospolitej. Studia z dziejów średniowiecza i czasów wczesnonowożytnych, t. 2, red. W. Bukowski i T. Jurek, Kraków 2012, s. 1325-26 (Aneks, nr 1); KDM I, nr 255.

${ }^{29}$ F. Sikora, Krag rodzinny i dworski Dymitra z Goraja i jego rola na Rusi, [w:] Genealogia - kręgi zawodowe i grupy interesu w Polsce średniowiecznej na tle porównawczym, red. J. Wroniszewski, Toruń 1989, s. 55, 57, 63-65, 68, 75-77, 87. 
źródła ukazują odmienny obraz stosunków między królem a bojarstwem niż ten, który prezentuje autor omawianej monografii.

Interesujący jest też pogląd I. Bojki na temat stosunku Kazimierza Wielkiego do zajętej prowincji i jej prawnego statusu w Królestwie Polskim. Autor stawia tezę, że król stosując tytulaturę Regnum Russiae akceptował odrębny status Rusi Halickiej, szanował jego nienaruszalność i starał się stworzyć unię dwóch równorzędnych królestw Polski i Rusi (s. 111-112). Teza ta pojawiła się już w polskiej historiografii, nie znalazła jednak uznania ${ }^{30}$. Problem ten nierozerwalnie wiąże się również ze stosunkami polsko-węgierskimi. W innym miejscu autor stwierdza, że aż do 1434 r. istniał odrębny status Regni Russiae charakteryzujący się terytorialną autonomią administracyjno-prawną, który był kontynuacją tradycji państwowych i prawnych księstwa halicko-włodzimierskiego (s. 216-217). Data graniczna nie jest jednoznaczna, gdyż proces likwidacji autonomii prawno-administracyjnej rozpoczął się już w 1387 r., przywilejami królewskimi dla ziem przemyskiej i lwowskiej, gwarantującymi ich integralność z Koroną ${ }^{31}$. W ciągu następnych dziesięcioleci wpływ polskich zwyczajów prawnych na ziemiach ruskich stawał się coraz większy, zaś wprowadzenie prawa polskiego w 1434 r. było tylko aktem prawnym kończącym proces ich społecznej adaptacji ${ }^{32}$. Wydaje się, że badacze powinni jeszcze raz przyjrzeć się sprawie używania tytulatury Regnum Russiae i rozważyć sprawę statusu Rusi w Królestwie Polskim.

Kolejnym zagadnieniem, które należy szerzej omówić, jest stanowisko starostów i ich funkcje w Polsce i na Rusi Halickiej. Igor Bojko w swych wywodach oparł się niestety na dziewiętnastowiecznej, zupełnie bałamutnej pracy Aleksandra Wejnerta ${ }^{33}$, powtarzając w większości bezkrytycznie jej tezy, choć miał do dyspozycji szeroką i znaną sobie literaturę ${ }^{34}$. Najpierw

${ }^{30}$ J. Sieradzki, Regnum Russiae. Polityka ruska Kazimierza Wielkiego. Krytyka dotychczasowych pogladów i zarys nowej konstrukcji. (Na marginesie pracy J. Dąbrowskiego „Korona Królestwa Polskiego”), „Kwartalnik Historyczny”, t. 65: 1958, s. 500-508.

${ }^{31}$ AGZ VII, nr 19; AGZ II, nr 17; AGZ III, nr 50.

${ }^{32}$ S. Kutrzeba, Przywilej jedlneński roku 1430 i nadanie polskiego prawa na Rusi, [w:] Ku czci Bolesława Ulanowskiego. Zbiór prac wydany w 25. rocznicę Jego uniwersyteckiej działalności przez profesorów i docentów Wydziału Prawa Uniwersytetu Jagiellońskiego, Kraków 1911, s. 288289; A. Janeczek, Udziat szlachty w kolonizacji, s. 59. Niektórzy badacze sądzą, że przekład polskich statutów ziemskich na język staroruski dokonany był już w pierwszej połowie XV w. właśnie na użytek sądownictwa na Rusi Halickiej: A. Vetulani, S. Roman, Średniowieczny ruski przekład statutów ziemskich Kazimierza Wielkiego i Władysława Jagietty, Wrocław 1950, s. 68-72. Odmiennego zdania jest J. Bardach, O przekladach ruskich polskich statutów ziemskich XIV i początku XV wieku, „Studia Źródłoznawcze”, t. 7: 1962, s. 77-98; idem, Ruskie przekłady polskich statutów ziemskich XIV i początku XV w., „Studia z Dziejów Państwa i Prawa Polskiego”, t. 3: 1999, s. 7-24.

${ }^{33}$ A. Wejnert, O starostach w Polsce do końca XVIII wieku z dołaczeniem wykazu ich miejscowości, Warszawa 1877.

${ }^{34}$ S. Kutrzeba, Starostowie, ich początki i rozwój w XIV w., „Rozprawy Akademii Umiejętności. Wydział Historyczno-Filozoficzny”, S. II, t. 20 (45): 1903, s. 231-348; L. Ehrlich, Starostwa w Halickiem w stosunku do starostwa lwowskiego w wiekach średnich (1390-1501), [w:] „Studya 
twierdzi, że urząd starosty w Polsce wprowadził Władysław Jagiełł, ustanawiając trzech starostów: małopolskiego, wielkopolskiego i kujawskiego ${ }^{35}$ (s. 227). Na następnych stronach podaje za A. Wejnertem błędne tezy mówiące o tym, że: urząd starosty został wprowadzony przez Bolesława Chrobrego, starostowie nie pełnili funkcji gospodarczych, istniał jakiś rzekomy podatek dla starostów, starostowie lokalni podlegali starostom generalnym ${ }^{36}$, przywilej koszycki skasował zwyczaj z czasów Bolesława Chrobrego mówiący o tym, że starostami mogli zostawać tylko Polacy. Niewłaściwe jest też twierdzenie, że starostwa obejmowały tylko dobra królewskie (s. 229). Należy bowiem rozróżniać okręgi jurysdykcyjne starostów (starostwa grodowe) od tenut i kluczy dóbr monarszych. Autor przedstawia również niepełną genezę powstawania starostw, twierdząc, że powstawały one wyłącznie na obszarach przyłączanych do Polski oraz na obszarach skonfiskowanych lub nabytych drogą zamiany (s. 229-30) ${ }^{37}$.

Bojko dzieli urząd starościński na starostów generalnych i zwyczajnych. Pisząc o powoływaniu starostów, nie rozróżnia starostów grodowych od mniejszych tenut, których zarządców również nazywano starostami i wszystkich określa mianem ,starostów zamkowych (grodowych)” (s. 232-33). Poza tym badania nad charakterem uprawnień i rangą starostów na Rusi Czerwonej powinny być prowadzone odrębnie dla poszczególnych starostw, ze względu

nad historyą prawa polskiego", t. 6, Lwów 1914; K. Maleczyński, Urzędnicy grodzcy i ziemscy lwowscy w latach 1352-1783, Lwów 1938; M. Wilamowski, Powstanie i początki hierarchii, s. 105-127; Ю. Зазуляк, Застави як елемент, s. 43-47; idem, Взаємовідносини старост, s. 75-86. Uzupełnić to należy o nieprzywołane przez autora prace: A. Gąsiorowski, Starostowie wielkopolskich miast królewskich $w$ dobie jagiellońskiej, Poznań 1981; idem, Początki sadów grodzkich w średniowiecznej Polsce, „Czasopismo Prawno-Historyczne”, t. 26: 1974, z. 2, s. 57-79; J. Kurtyka, Odrodzone Królestwo. Monarchia Władysława Łokietka i Kazimierza Wielkiego w świetle nowszych badań, Kraków 2001, s. 122-147; idem, Z dziejów walki szlachty ruskiej, s. 84-86; J. Sperka, Urzędnicy Władysława Opolczyka na Rusi (1372-1378), [w:] Społeczeństwo Polski Średniowiecznej. Zbiór studiów, T. 10, red. S. K. Kuczyński, Warszawa 2004, s. 83-102; idem, Otoczenie Władyslawa Opolczyka w latach 1370-1401, Katowice 2006, s. 73-90.

${ }^{35}$ Wszystkie dotychczasowe badania jednoznacznie stwierdzały, że urząd starosty wprowadził na ziemiach polskich Wacław II (S. Kutrzeba, Starostowie, s. 233; J. Kurtyka, Odrodzone Królestwo, s. 122). Starostowie w Małopolsce występowali tylko epizodycznie w czasach Wacława II, potem nie występowali tam aż do śmierci Kazimierza Wielkiego i nawet później mieli znacząco różne kompetencje od starostów w innych polskich prowincjach (S. Kutrzeba, Starostowie, s. 23335, 319-21, 324-331; F. Sikora, Wielkorzady krakowskie na przetomie XIV i XV wieku, [w:] Urzędy dworu monarszego dawnej Rzeczpospolitej i państw ościennych, red. A. Gąsiorowski, R. Skowron, Kraków 1996, s. 103-108; J. Kurtyka, Odrodzone Królestwo, s. 123, 125, 129, 136-47).

${ }^{36}$ Wszyscy starostowie grodowi (cum iurisdictione) podlegali bezpośrednio królowi. Tam gdzie występowali starostowie generalni (Wielkopolska i Ruś Czerwona), inne starostwa grodowe były wyodrębniane ze starostwa generalnego i ich starostowie nigdy nie podlegali starostom generalnym: L. Ehrlich, Starostwa w Halickiem, passim; A. Gąsiorowski, Starostowie, s. 6, 9-10.

${ }^{37}$ Starostwa powstawały w XIV i XV w. na obszarze całej Polski poprzez dzielenie się i wyodrębnianie nowych starostw oraz powoływanie starostów na obszarach, na których do tej pory ich nie było. 
na różnorodność czynników wpływających na ich kształtowanie, lokalną specyfikę i brak jednolitego modelu urzędu starościńskiego na tym terytorium. Fragment pracy dotyczący genezy, organizacji i kompetencji urzędu starosty zarówno w Polsce, jak i na Rusi Czerwonej wykazuje więc bardzo poważne braki, zwłaszcza w znajomości ustaleń podstawowej literatury.

Omawiając strukturę zarządu lokalnego i podział administracyjny na Rusi Czerwonej po wprowadzeniu tam w 1434 r. prawa polskiego, autor wymienia ustanowione wówczas województwa ruskie i bełskie, nie wspominając o wo-

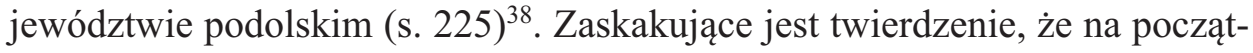
ku XVI w. w Polsce dokonano reformy administracyjnej wprowadzając do istniejącego już podziału na województwa i starostwa (sic!), jeszcze podział na nowe jednostki administracyjne - powiaty (s. 225). Dodatkowo autor ubolewa, że powiaty te były dość nierówne pod względem liczby osad, cytując za Przemysławem Dąbkowskim dane o powiatach: halickim, czerwonogrodzkim, koropieckim, kołomyjskim, śniatyńskim i trembowelskim ${ }^{39}$. Stwierdzenie autora, że do końca XV w. na Rusi Halickiej funkcjonował podział na województwa i starostwa, jest zbyt ogólnikowe i niejasne. W Polsce istniał wówczas podział terytorialny na województwa, ziemie i powiaty ziemskie, który był wykorzystywany w określaniu przynależności terytorialnej i położenia geograficznego głównie ze względu na swoje znaczenie w organizacji sądownictwa ziemskiego. Ponadto $\mathrm{w}$ ramach poszczególnych województw istniał także podział na okręgi jurysdykcyjne, na których czele stali starostowie grodowi. Okręgi te nie zawsze pokrywały się z podziałem na ziemie i powiaty ziemskie. Tak było również na Rusi Czerwonej. Podział na powiaty ziemskie funkcjonował w Polsce co najmniej od drugiej połowy XIV w., a od 1434 r. - na Rusi. Z kolei termin districtus, jako nazwa jednostki terytorialnej, występował w Polsce już od XIII w., a powiat, jako polski odpowiednik terminu districtus, znany jest w źródłach od drugiej połowy XIV w. i występuje tylko w znaczeniu okręgu sądowego ${ }^{40}$. Na Rusi termin districtus najpierw był łacińskim synonimem ruskiej wołości, która w polskiej literaturze dotyczącej drugiej połowy XIV i XV w. nazywana jest powiatem grodowym, okręgiem

${ }^{38}$ Województwo bełskie zostało ustanowione w 1462 r. w wyniku inkorporacji ziemi bełskiej do Korony, A. Janeczek, Osadnictwo pogranicza, s. 33.

${ }^{39}$ P. Dąbkowski, Podział administracyjny województwa ruskiego i betskiego w XV wieku, [w:] Zabytki dziejowe, t. 5, Lwów 1939, s. 7, 43, 52, 53, 171, 176 (I. Bojko błędnie podaje w przypisie stronę 139 tej pracy, na której nie ma żadnej z wymienionych przez niego informacji).

40 J. Bardach, Powiat w Polsce średniowiecznej, „Czasopismo Prawno-Historyczne”, t. 19: 1967, z. 2, s. 139-155; A. Gąsiorowski, „Districtus” w Wielkopolsce poczatków XIV wieku (Z zagadnień zarzadu terytorialnego Polski średniowiecznej), „Roczniki Historyczne”, t. 32: 1966, s. 173-193; S. Kutrzeba, Sąy grodzkie i ziemskie w wiekach średnich, cz. VIII. Województwo ruskie, „Rozprawy Akademii Umiejętności. Wydział Historyczno-Filozoficzny”, t. 42: 1902, s. 212-214. M. Крикун, Земські уряди на украӥнських землях у XV-XVIII століттях, „Записки Наукового Товариства імені Шевченка", t. 228: 1994, s. 87-89. 
grodowym lub dystryktem. Niektóre z tych dystryktów (wołości) w XV w. pokrywały się z okręgami jurysdykcyjnymi starostów grodowych, inne pozostały reliktami dawnych wołości (okręgów grodowych) z czasów książęcych niemających w XV w. żadnego znaczenia w strukturze administracji terytorialnej, inne adaptowane były na potrzeby zarządu dóbr monarszych. Pojawiały się także nowo tworzone okręgi zarządu dóbr monarszych (klucze dóbr, tenuty, starostwa niegrodowe), które też określano w XV w. mianem distric$t u s^{41}$. Przemysław Dąbkowski w swej pracy określił wszystkie te kategorie mianem powiatu ${ }^{42}$. Wymienione przez I. Bojkę powiaty halicki i kołomyjski były powiatami ziemskimi, których obszar zarazem pokrywał się z okręgiem jurysdykcyjnym starostów halickiego i kołomyjskiego. Powiat koropiecki był jedynie reliktem wołości bez żadnego znaczenia w systemie administracyjnym, zaś śniatyński stanowił osobny okręg jurysdykcyjny starostów grodowych, lecz nie był powiatem ziemskim. Jednak kilka stron dalej (s. 236-237) autor, nie zważając na swe wcześniejsze ustalenia, przedstawia zgodny z rzeczywistością podział Rusi na powiaty ziemskie dokonany w 1434 r., tym razem opierając się na pracy Stanisława Kutrzeby ${ }^{43}$.

$\mathrm{Z}$ przekształceniami $\mathrm{w}$ administracji też wiązał się problem po $1434 \mathrm{r}$. dóbr monarszych. W sprawie ich genezy autor stwierdza:

${ }^{41}$ S. Kutrzeba, Sądy grodzkie i ziemskie w wiekach średnich, cz. VIII. Województwo ruskie, „Rozprawy Akademii Umiejętności. Wydział Historyczno-Filozoficzny”, t. 42: 1902, s. 225-28; O. Balzer, rec.: X. Liske, AGZ, t. XIV: Najdawniejsze zapiski sądów lwowskich 1440 do 1456, Lwów 1889, „Kwartalnik Historyczny” t. 4: 1890, s. 555-556; P. Dąbkowski, Zaginione księgi sqdowe województwa ruskiego i betskiego, „Studya nad Historyą Prawa Polskiego”, t. 8: 1921, z. 1, s. 15, 18; A. Janeczek, Osadnictwo pogranicza, s. 23-24, 29; idem, Podhoraj - zaginiony gród pogranicza polsko-ruskiego, „Kwartalnik Historii Kultury Materialnej”, t. 33: 1985, nr 1-2, s. 12; idem, Granice a procesy osadnicze, s. 292-93 ; idem, System grodowo-terytorialny, s. 143, 145-153; idem, Faktorie, powiaty i dwory, s. 424 (przyp. 13), 439-445; J. Kurtyka, Wstęp, [w:] Urzędnicy podolscy XIV-XVIII wieku. Spisy, Kórnik 1998, s. 13-14, 18-21; idem, Podole w średniowieczu i okresie nowożytnym: obrotowe przedmurze na pograniczu cywilizacji, [w:] idem, Podole $w$ czasach jagiellońskich. Studia i Materiały, oprac. M. Wilamowski, Kraków 2011, s. 137-145; J. Szyszka, Ksztaltowanie się podziatów terytorialnych Rusi Czerwonej na przykladzie ziemi lwowskiej, „Średniowiecze Polskie i Powszechne”, t. 3 (7), red. J. Sperka i B. Czwojdrak, s. 120-140.

${ }^{42}$ P. Dąbkowski, Podział administracyjny, s. 7, 43, 52, 53, 171, 176. Autor ten wyraża przekonanie o ruskiej genezie wszystkich tych powiatów i wyciąga błędny wniosek o istnieniu jednolitego podziału administracyjnego (zarówno przed, jak i po wprowadzeniu prawa polskiego), na który składało się wszystkie 30 wymienionych przez niego powiatów. W swej wcześniejszej pracy idzie nawet o krok dalej uważając, że w każdym z tych powiatów istniała jednolita publiczna jurysdykcja, zgadzając się w tym z X. Liskem, zaś zdecydowanie przecząc S. Kutrzebie i O Balzerowi, zob. P. Dąbkowski, Zaginione księgi, s. 10-11, 17; X. Liske, Przedmowa, [w:] AGZ, t. 11, wyd. X. Liske, Lwów 1886, s. IX-X; idem, Przedmowa, [w:] AGZ, t. 13, wyd. X. Liske, Lwów 1888, s. X-XI; idem, Przedmowa, [w:] AGZ, t. 14, wyd. X. Liske, Lwów 1889, s. IX-X; O. Balzer, rec. z: X. Liske, $A G Z$, t. XIII: Najdawniejsze zapiski sądów przemyskich i przeworskiego 1436-1468, Lwów 1888, „Kwartalnik Historyczny” t. 3: 1889, s. 514-15; idem, rec. z: X. Liske, AGZ, t. XIV: Najdawniejsze zapiski sąów lwowskich 1440 do 1456, Lwów 1889, „Kwartalnik Historyczny” t. 4: 1890, s. 553-556; S. Kutrzeba, Sady grodzkie i ziemskie, s. 212-214.

${ }^{43}$ S. Kutrzeba, Studya do historyi sądownictwa w Polsce. Serya 1, Lwów 1901, s. 95-96. 
,jednocześnie z wprowadzeniem nowego podziału administracyjnego w Królestwie Polskim wynikła konieczność zorganizowania zarządu nad wielkimi posiadłościami ziemskimi dawnych książąt halickich i osób, które nie chcąc pogodzić się z polską okupacją, opuściły Ruś Halicką. Ziemie te przeszły na własność króla polskiego i nazywane były królewszczyznami. Ogólna powierzchnia majątków królewskich na ówczesnej Rusi Halickiej stanowiła 1/3 całego terytorium Królestwa Polskiego [sic!]”.

Tymczasem w 1434 r. nie zaistniała konieczność organizacji zarządu rzekomo zajętymi dobrami. Kto zarządzał nimi przez prawie sto lat? W jaki sposób królewszczyzny na Rusi Halickiej mogły stanowić 1/3 terytorium Polski? Autor powołuje się w tym miejscu na pracę Jurija Hoszki, gdzie znajdujemy wyjaśnienie. Opisana tam sytuacja nie dotyczy 1434 r., lecz sytuacji po zajęciu Rusi przez Kazimierza Wielkiego. W pracy J. Hoszki ostatnie zdanie brzmi: „Ogólna powierzchnia majątków królewskich na ówczesnej Rusi Halickiej stanowiła 1/3 całego terytorium [Rusi], królowi należał się całkowicie tylko powiat samborski" ${ }^{4}$. Tak więc chodzi oczywiście o to, że królewszczyzny na Rusi stanowiły $1 / 3$ jej terytorium. Doprecyzujmy, że jest to poziom własności monarszej zbliżony do poziomu znanego z ok. połowy XV w. dla ziemi lwowskiej (28\%) i dla przemyskiej pod koniec XVI w. (około 30\%). W ziemi sanockiej i bełskiej był on w połowie XV w. jeszcze niższy $(20 \%)^{45}$. Ostatnie badania wykazują, że w połowie XIV w. do dóbr monarszych (zagospodarowanych oraz wolnych, stanowiących rezerwę królewską) tylko w ziemi lwowskiej należało ok. 70\% wszystkich istniejących tam osad ${ }^{46}$. Nie ma też żadnego potwierdzenia źródłowego - o czym wspomniano wyżej - tezy o oporze bojarskim wobec króla i wrogim opuszczeniu kraju w geście protestu przeciw zajęciu Rusi przez Kazimierza Wielkiego.

Genezy tak wielkiego obszaru dóbr monarszych należy raczej dopatrywać w stosunkach społecznych i własnościowych na Rusi Halickiej w okresie książęcym. Zgodnie z najnowszą opinią badaczy rosyjskich, na terytorium Rusi Halickiej do połowy XIII w. istniała bardzo nieliczna własność alodialna (votčina), a głównym sposobem korzystania z dóbr ziemskich (właściwie $\mathrm{z}$ dochodów $\mathrm{z}$ tych dóbr w postaci danin i świadczeń) było beneficjum (kormlenja $)^{47}$. Taki stan rzeczy powodował, że większość ziemi była w dyspozy-

44 Ю. Гошко, Звичаєве право населення украйнських Карпат та Прикарпаття XIV-ХІХ ст., Львів 1999, s. 22.

${ }^{45}$ A. Janeczek, Polska ekspansja, s. 611-616; idem, Migracje szlachty polskiej, s. 161; idem, Udziat szlachty w kolonizacji, s. 71.

${ }^{46}$ J. Szyszka, Dobra monarsze w ziemi lwowskiej w latach 1340-1504, Rozprawa doktorska przygotowana pod kierunkiem dra hab. Jana Wroniszewskiego, prof. UMK w Toruniu, Toruń 2013.

47 И.Я. Фроянов, Киевская Русь. Главные черты сочиально-экономического строя, Санкт-Петербург 1999, s. 166-178; С.С. Пашин, Галиикое боярство XII-XIII вв., „Вестник Ле- 
cji władcy, a ludność ją zamieszkująca użytkowała ją prawdopodobnie na podstawie „umów” z władcą na różnych prawach grupowych ${ }^{48}$. Część ziemi leżącej bliżej grodów mogła być eksploatowana bardziej intensywnie i podlegać ściślejszej kontroli urzędników, gdyż zapewne stanowiła bezpośrednie zaplecze gospodarcze owych grodów. Pozostałe obszary były w użytkowaniu lokalnych gmin (ob̌̌činy) składających się z mieszkańców pobliskich osad jednodworczych grupujących się w lokalną społeczność i mających - być może - wspólne obowiązki wobec książąt (daniny i świadczenia), albo leżały odłogiem ze względu na niski poziom zaludnienia i nadmiar wolnej zie$\mathrm{mi}^{49}$. Dwie ostatnie kategorie stanowiły wspólnie, jak określił to słusznie Andrzej Janeczek, rezerwę ziemi monarszej ${ }^{50}$. Te zagospodarowane obszary, jak i nieużytki, z chwilą zajęcia Rusi przez polskiego króla weszły w skład dóbr królewskich, do których monarcha rościł sobie prawo wynikające $\mathrm{z}$ regale ziemnego i uprawnień władczych. Ludność użytkująca te tereny stała się automatycznie poddanymi dóbr królewskich. Mogło to spotkać również niektóre kategorie drobnych bojarów (służków), choć do ich obowiązków należała służba wojskowa ${ }^{51}$. Wówczas gospodarka w dobrach królewskich na Rusi (zarówno ze względu na ich rozmiar, poziom rozwoju technik rolnych, jak i rzadkie osadnictwo) była oparta na dotychczasowych daninach i świadczeniach, nie podlegała przeobrażeniom w kierunku modernizacji, intensyfikacji produkcji oraz powstawaniu opartych na czynszu osad prawa niemieckiego. Natomiast stosunki społeczne przypominały te znane z czasów książęcych. Wówczas sytuacja drobnego bojarstwa nie ulegała radykalnym zmianom. Jednak z czasem (zwłaszcza w okresie rządów Władyslawa Opolczyka i po 1387 r.), gdy zarządcy dóbr monarszych intensyfikowali i modernizowali go-

нинградского Государственного Университета", Серия 2, Но. 23: 1985, Вып. 4, s. 16-17, 20; C.С. Пашин, Червонорусские акты XIV-XV вв. и грамоты князя Льва Даниловича, Тюмень, 1996, s. 10-11, 26-27, 35; K. Krupa, Bojarzy w Haliczu (koniec XII - I polowa XIII w.), [w:] Fasciculi Historici Novi. T. 2. Z dziejów średniowiecznej Europy Środkowo-Wschodniej, red. J. Tyszkiewicz, Warszawa 1998, s. 51-53, 56; A. Janeczek, Migracje szlachty polskiej, s. 152; idem, Udziat szlachty w kolonizacji, s. 63-64.

${ }^{48}$ A. Janeczek, Udziat szlachty w kolonizacji, s. 64.

${ }^{49}$ Idem, Migracje szlachty polskiej, s. 152; idem, Udziat szlachty w kolonizacji, s. 60, 64.

${ }^{50}$ Idem, Migracje szlachty polskiej, s. 154; idem, Udziat szlachty w kolonizacji, s. 64.

${ }^{51}$ Status służków, bojarów osadzonych w okolicach grodów, przypominał być może sytuację milites castrenses w Polsce XI-XII w. Jednak posiadanie przez niektórych z nich drobnych dziedzicznych majątków bardziej przypominało status przedimmunitetowego rycerstwa włodyczego z przełomu XII i XIII w., cieszącego się prawem rycerskim (ius militare) będącym jednym (choć uprzywilejowanym) z książęcych praw grupowych, por. K. Buczek, Prawo rycerskie i powstanie stanu szlacheckiego w Polsce, [w:] idem, Studia z dziejów ustroju spoleczno-gospodarczego Polski piastowskiej. T. 3, oprac. W. Bukowski, Kraków 2010, s. 157-169; T. Jurek, Geneza szlachty polskiej, [w:] Šlechta, moc a reprezentace ve středoveku. Colloquia mediaevalia Pragensia 9, Praha 2007, s. 85-99; K. Modzelewski, Organizacja gospodarcza państwa piastowskiego X-XIII wieku, Poznań $2000^{2}$, s. 180-194; S. Gawlas, O ksztatt zjednoczonego Królestwa. Niemieckie władztwo terytorialne a geneza społeczno-ustrojowej odrębności Polski, Warszawa 2000, s. 86-88. 
spodarkę w poszczególnych kluczach dóbr, głównie poprzez kolonizację na prawie niemieckim oraz zakładanie folwarków, zaś dotychczasowe prawo ruskie było zastępowane polskim prawem ziemskim, drobne bojarstwo służebne znalazło się na pograniczu stanów. Stanowili oni enigmatyczną grupę zwaną w źródłach ludźmi królewskimi lub ziemianami królewskimi (homines regales, terrigenes regales), którzy mieli dziedziczne prawo do ziemi i pełnili służbę wojskową, jednak nie wszyscy oni weszli później w skład społeczności szlacheckiej ${ }^{52}$. Być może tymi terminami określano zarówno niektóre kategorie ludności pospolitej, jak i drobnego bojarstwa. Bojarzy ci mogli jednak udowodnić swą dziedziczną i alodialną własność poprzez posiadane dokumenty nadań lub, w przypadku ich braku, poprzez przysięgę i świadków potwierdzających dawną ( $a b$ antiquo) osiadłość na swych dobrach i obronę szlachectwa. Jednak część spośród nich nie zdołała, lub nie była w stanie, udowodnić swej własności ${ }^{53}$.

Krytycznego omówienia wymaga wiążący się ściśle z powyższym zagadnieniem problem własności i form władania ziemią. Już w rozdziale drugim I. Bojko wspomina o dwóch formach dzierżenia ziemi przez szlachtę: beneficjum i lennie (s. 147-48). W dalszej części pracy (za K.E. Liwancjewem) twierdzi, że były to votčina i pomistia ${ }^{54}$. Pierwsza z nich oznaczała - według obydwu autorów - własność dziedziczną alodialną, a druga - beneficjum. To ostatnie było nadawane jako nagroda za wierną służbę i nie podlegało spadkowi ani dziedziczeniu, zaś beneficjenci popadali z tego tytułu w zależność lenną od władcy i byli zobowiązani do ciągłej służby wojskowej lub innej, której przerwanie pozbawiało ich majątku (s. 416) ${ }^{55}$. Liwancjew dość bezrefleksyjnie dla określenia systemu panującego w Polsce w czasach wczesnopiastowskich i do końca rozbicia dzielnicowego użył też terminu pomjestja, oznaczającego formę dzierżenia ziemi, którą w XIV w. zaczęto wprowadzać w Państwie Moskiewskim ${ }^{56}$. Podobnie I. Bojko terminologię tę próbował za-

${ }^{52}$ A. Janeczek, Migracje szlachty polskiej, s. 152-155; idem, Udzial szlachty w kolonizacji, s. $65-66,81,88$.

${ }^{53}$ Idem, Udzial szlachty $w$ kolonizacji, s. 65-66, 81; Ю. Зазуляк, Veri et perpetui terrarum Russie heredes: Шляхи легітимації прав на земельну власність серед рускої иляхти в середині $X V$ cm., „Вісник Львівського Університету. Серя історічна”, Вип. 34, 1999, s. 95-107.

54 К.Е. Ливанцев, История государства и права феодальной Польши XIII-XIV вв., Ленинград 1958, s. 109.

55 Taki system pod nazwą „wysługa” znany był w XII-wiecznych Czechach, zob. S. Russocki, Z badań nad czeskim systemem beneficjalnym, „Czasopismo Prawno-Historyczne”, t. 23:1971, z. 1, s. 36-38; idem, Rola ,fidelitas” $i$,, beneficjum” w ustroju państw stowiańskich, [w:] Z polskich studiów slawistycznych. Seria 4. Historia. Prace na VII Międzynarodowy Kongres Slawistów w Warszawie 1973 r., Warszawa 1972, s. 69.

${ }^{56} \mathrm{~W}$ systemie pomiestnym władca oddawał bojarowi w użytkowanie własną ziemię na określony czas, zwykle dożywotnio, jednak pod bezwzględnym warunkiem stałej służby, zazwyczaj wojskowej. Użytkownik nie miał do tej ziemi żadnych praw własnościowych, mógł z niej tylko korzystać, zob. A. Kijas, Gospodarstwo wlasne feudata na Wielkorusi od polowy XIV do polowy XVI 
stosować dla stosunków społecznych na Rusi Halickiej i w Polsce w drugiej połowie XIV i w XV stuleciu. Zdaniem autora - w źródłach takie nadania były nazywane „wysłużone”, choć nie podaje on na to żadnych przykładów. Terminy „wysługa” i „wysłużone” istotnie pojawiają się w źródłach nie tylko na Rusi Halickiej, ale i w Małopolsce, odnoszą się jednak do majątku będącego wynagrodzeniem otrzymanym najczęściej od władcy za służbę i oddane przysługi. Mogły zawierać się w nich zarówno nadania ziemskie, zastawy, jak i sumy zabezpieczone na nieruchomościach. W dokumentach i aktach wyróżniano je jako część składową całego majątku w odróżnieniu od dóbr odziedziczonych (najczęściej ze względu na przepisy prawa spadkowego) ${ }^{57}$. Natomiast forma władania ziemią charakterystyczna na Rusi Halickiej, przynajmniej dla części bojarstwa ruskiego i wołoskiego ${ }^{58}$, zwana było prawem służebnym (ius servile). Nie ulega wątpliwości, że w XIV w. istniały zwyczajowe formy władania ziemią na Rusi Halickiej. Jednak brak źródeł i kompleksowych badań nie pozwoliły do tej pory na ich scharakteryzowanie. Wpływ zachodniego prawa lennego ${ }^{59}$, jego podobieństwo do zwyczajów ruskich, a być może ich wzajemna konwergencja spowodowały, że już na początku XV w. stosowano zamiennie nazwę ius feodale alias szluske ${ }^{60}$. Podobnie jak prawo lenne, również prawo służebne uznawane było za mniej atrakcyjne dla właścicieli, zatem starali się oni o przeniesienie de iure servili in ius terrestre ${ }^{61}$. Również autor

wieku, Poznań 1973, s. 22, 24; idem, System pomiestny w Państwie Moskiewskim w XV-pierwszej połowie XVI wieku, Poznań 1984, s. 7-9, 36-38, 47, 53, 59-62.

${ }^{57}$ AGAD d.p. 7289; AGZ XIV, 650; SPPP II, nr 1332, 2818; więcej przykładów zob. Słownik Staropolski. T. 10, red. S. Urbańczyk, Kraków 1988-1993, s. 560-561.

${ }^{58}$ Elity rycerstwa wołoskiego, np. Daniło Dadźbogowicz, dostawały nadania na pełnym prawie dziedzicznym (KDM III/844; Kraków, Archiwum Narodowe, Archiwum Aktów Dawnych miasta Krakowa, nr 861, ed. zob. L. Wyrostek, Ród Dragów-Sasów na Węgrzech i Rusi Halickiej, „Rocznik Polskiego Towarzystwa Heraldycznego”, t. 9: 1931-32, s. 78, przyp. 2 - edycja fragmentów dokumentu). Jednak część, zwłaszcza mniej zamożnych osadników, otrzymywała ziemię na prawie służebnym, podobnie jak drobni bojarzy ruscy. Drobniejsze rycerstwo wołoskie i kniaziowie dzierżyli dobra, które pozostawały własnością monarszą. Dzierżenie polegało prawdopodobnie wyłącznie na użytkowaniu ziemi w zamian za pewne obowiązki, zwykle wojskowe, choć nadal pozostawała ona własnością królewską. Przykładem są Wołosi osadzeni w dobrach królewskich: w Horożanie Małej (AGZ II, nr 78; XIV, nr 3558), Werbiżu (AGZ II, nr 35 = Украӥнські грамоти. Том 1: XIV в. і периа половина XV в., под. В. Розов, Київ, 1928, nr 39 ), Jaśniskach (AGZ V, nr 131 = MRPC, nr 145). Więcej podobnych przykładów zob. G. Jawor, Osady prawa wołoskiego i ich mieszkańcy na Rusi Czerwonej w późnym średniowieczu, Lublin 2004, s. 84-123.

${ }^{59}$ Być może polscy władcy pod wpływem prawa niemieckiego modyfikowali zasady prawa służebnego, dodając do nich np. obowiązki sołtysów, takie jak określony wymiar służby wojskowej.

${ }^{60} \mathrm{AGZ}$ V, nr 30 = KDP I, nr 134. W przypadku tej glosy w literaturze obecna jest również uprawniona hipoteza, iż słowo szluske oznacza śląskie. Wówczas prawo lenne nazywane byłoby śląskim, zob. J. Kus, Manowie jarosławscy. Z zagadnień stosunków lennych na Rusi Czerwonej (XIV-XVI w.), „Przemyskie Zapiski Historyczne”, t. 3: 1985, s. 17). Wydaje się jednak, że w zestawieniu z zapisem ius servile w dokumencie dla Obłaźnickich z 1435 r. (AGZ III, nr 107) bardziej prawdopodobne jest wywodzenie słowa szluske od słowa sługa.

${ }^{61}$ AGZ III, nr 107. 
omawianej pracy podaje przykład zamiennego zastosowania terminu ,prawo feudalne" i ,służebne", przytaczając królewski dokument z 1519 r., w którym władca zwolnił wasala z ,prawa służebnego czyli feudalnego" (s. 418). Jednak nic nie świadczy, aby forma ta miała cokolwiek wspólnego z pomjestją. Także dokumenty nadawcze wystawiane na Rusi Halickiej od połowy XIV w. oraz potwierdzenia wcześniejszych nadań książęcych nie wykazują istnienia formy dzierżenia ziemi zbliżonej do moskiewskich pomjestji ani na terenie Polski, ani Rusi ${ }^{62}$.

W innym miejscu, opierając się na tezie Wasyla Inkima, autor twierdzi, że na Rusi Halickiej istniała ruska odmiana prawa lennego, którą stosowali tam również Kazimierz Wielki i Władysław Opolczyk. Miała ona ponoć następujące cechy: ściśle określony wymiar służby wojskowej, obowiązek rezydencji, zakaz obrotu nadanymi dobrami bez zgody króla przez 3 lata od nadania, opłata podymnego 2 gr. od kmiecia oraz świadczenia na rzecz zamków i umocnień (s. 414). Jest to teza dyskusyjna, niepotwierdzona szczegółową analizą tych nadań ${ }^{63}$. Klauzula ściśle określonego wymiaru służby wojskowej, na której opiera on swą teorię, zdaniem niektórych badaczy może wskazywać na nadanie warunkowe ${ }^{64}$. Sam obowiązek służby wojskowej wynikał z królewskiego regale i obejmował zarówno dobra dziedziczne (alodialne), jak i dzierżone na prawie lennym oraz na prawie niemieckim (np. własność wójtowską i sołtysią) ${ }^{65}$. Poza tym, na 18 nadań dokonanych przez Kazimie-

${ }^{62}$ Większość dokumentów Kazimierza Wielkiego to nadania określane jako wieczyste (donatio perpetua) i dziedziczne, których formularz niczym nie różnił się od nadań na prawie dziedzicznym stosowanych w tym czasie w Polsce. Jedyną różnicą był określony wymiar służby wojskowej. Władysław Opolczyk zaczął wprowadzać nadania lenne, choć kontynuował również model wypracowany w kancelarii poprzedniego władcy: A. Prochaska, Lenna i maństwa na Rusi i Podolu, „Rozprawy i Sprawozdania z Czynności i Posiedzeń Polskiej Akademii Umiejętności w Krakowie. Wydział Historyczno-Filozoficzny", t. 42: 1901, s. 4-8, 11; A. Janeczek, Migracje szlachty polskiej, s. 159; idem, Udziat szlachty w kolonizacji, s. 75-76.

${ }^{63}$ W. Inkin, opierając się na zdaniu A. Prochaski, o braku nadań lennych na Rusi za Kazimierza Wielkiego, jednocześnie podzielił dyskusyjną tezę L. Wyrostka, że wprowadzone przez Opolczyka przepisy prawa lennego „są tylko próbą ujęcia w formę prawną obowiązków rycersko-ziemiańskich, które istniały z dawien dawna" oraz że większość nadań tego księcia dotyczyła autochtonów. Jest to nieprawdą, gdyż tylko 2-3 nadania na 13 wszystkich nadań na prawie lennym w ziemi lwowskiej, dotyczyły Rusinów, Wołochów lub Ormian. Inkin powtarza też zasady prawa ruskiego sformułowane przez L. Wyrostka (określony wymiar służby wojskowej, obowiązek rezydencji, zakaz obrotu ziemią bez zgody króla, obowiązek uiszczania podymnego, danina owsiana, świadczenia na rzecz grodów), idąc jednak dalej i nazywając ten system ruską odmianą prawa lennego, zob. В. Інкін, Сільське суспільство Галицького Прикарпаття у XVI-XVIII століттях: історичні нариси, Львів 2004, s. 136-137; A. Prochaska, Lenna i maństwa, s. 7, 11; L. Wyrostek, Ród Dragów-Sasów, s. 139, 141.

${ }^{64} \mathrm{~S}$. Russocki, Instytucje - wptywy - kultura: warunkowe nadania ziemi w procesie centralizacji feudalnych monarchii środkowo-wschodniej Europy późnego średniowiecza, „Przegląd Humanistyczny", t. 28: 1984, nr 1, s. 7-8.

${ }^{65}$ L. Łysiak, Własność soltysia (wójtowska) w Małopolsce do końca XVI wieku, Kraków 1964, s. 169; A. Janeczek, Udziat szlachty w kolonizacji, s. 75-76, 80. 
rza Wielkiego na Rusi Czerwonej, określony wymiar służby wojskowej został zawarty jedynie w $8 \mathrm{z}$ nich ${ }^{66}$. W 2 nadaniach, w których występują klauzule zastrzegające, że odbiorca ma dzierżyć ziemię zgodnie ze zwyczajem ziemi ruskiej, tak jak pozostała szlachta tej ziemi, nie ma mowy o określonym wymiarze służby wojskowej ${ }^{67}$. Tak więc odwołanie się do zwyczaju ruskiego nie oznacza jednocześnie, że w nadaniu określono wymiar służby wojskowej. Natomiast Kazimierz Wielki, potwierdzając 3 nadania dawnych książąt halickich, dodał odbiorcom obowiązek służby wojskowej w określonym wymiarze ${ }^{68}$. Można $z$ tego wnioskować, że obowiązek służby wojskowej w ściśle określonym wymiarze nie był związany z prawem ruskim, a pojawił się $\mathrm{w}$ dokumentach z ziem ruskich $\mathrm{z}$ inicjatywy Kazimierza Wielkiego lub jego kancelarii. Wynikało to z praktycznych potrzeb i oparte było na rozwiązaniach zaczerpniętych z prawa lennego lub, co bardziej prawdopodobne, z niemieckiego prawa ziemskiego (landrecht) stosowanego w Polsce w nadaniach prawa niemieckiego (wójtostw i sołectw) ${ }^{69}$. W ruskim prawie zwyczajowym służba wojskowa $\mathrm{z}$ tytułu dzierżenia dóbr prawdopodobnie nie była ściśle określona, podobnie jak w polskim prawie ziemskim.

Klauzula obowiązku rezydencji nie była stosowana powszechnie i wynikała z wojskowego i obronnego charakteru osadnictwa na Rusi oraz konieczności głębokiej modernizacji i zwiększenia zaludnienia kraju. Klauzuli tej nie ma w żadnym z 18 nadań Kazimierza Wielkiego na Rusi Czerwonej ani w żadnym z 3 potwierdzeń wcześniejszych nadań książąt halickich. Była ona wprowadzana do dokumentów nadawczych przez Władysława Opolczyka i stosowana wyłącznie w nadaniach na prawie lennym (choć nie we wszystkich). Na 30 znanych z treści nadań Opolczyka na obszarze ziemi lwowskiej, 14 było na prawie lennym, z których tylko w 3 wystąpiła klauzula obowiązku rezydencji ${ }^{70}$. Zakaz obrotu ziemi przez 3 lata bez zgody króla również trafiał

${ }^{66}$ H. Paszkiewicz Polityka ruska Kazimierza Wielkiego, Warszawa 1925 (przedruk: Kraków 2002), s. 186; KDM III, nr 715; KDM I, nr 252 ZDM VIII, nr 2532; Hrusz.Mat. 1 = KDM III, nr 741; AGZ II, nr 2; KDM III, nr 807; KDM III, nr 816.

${ }^{67}$ S. Barącz, Archiwum domowe, s. 486-488 = J.A. Spież, Trzy niedocenione czternastowieczne dokumenty, s. 1325-26 (Aneks, nr 1), KDM III, nr 739.

${ }^{68}$ AGAD, dok. perg. 7231; ZDM IV, nr 958; KDM III, nr 743.

${ }^{69}$ Przypadek zastosowania tegoż rozwiązania przez Bolesława Jerzego Trojdenowica, wspomniany przez L. Wyrostka, może dowodzić, nie tyle jego wywodzenia się ze zwyczajów ruskich, jak chce tenże badacz. Może wręcz wskazywać na Mazowsze jako źródło jego pochodzenia, gdzie nadania z określonym wymiarem służby wojskowej były w XIV w. w powszechnym zastosowaniu (MRPS IV, nr 16885; L. Wyrostek, Ród Dragów-Sasów, s. 140; S. Russocki, Nadania ziemi ,ad servitia communia" a obowiązek stużby wojskowej na Mazowszu, [w:] Miscellanea Iuridica złożone w darze Karolowi Koranyiemu w czterdziestolecie pracy naukowej, Warszawa 1961, s. 111 i n.; idem, Instytucje - wplywy - kultura, s. 7).

70 Львівська національна наукова бібліотека України імені В. Стефаника НАН України, ф. 77 [Kolekcja Petruszewycza], оп. 1, спр. III ACП-1; AGAD, Tzw. Metryka Litewska, sygn. IV. B. 9 (Księga wpisów przywilejów na dobra w województwie ruskim przedkładanych podczas „,rewizji listów" w 1563/64 r.), k. 367v-368; AGZ II, nr 5. 
się rzadko, podczas gdy całkowity zakaz obrotu bez zgody seniora obecny w prawie lennym, nie zawsze jednak był wyszczególniany w dokumentach nadawczych. W wymienionych 30 dokumentach Opolczyka, tylko w 2 jest mowa o wymaganej zgodzie na alienację (w tym 1 to nadanie lenne, zaś drugi znany jest tylko z enigmatycznej wzmianki, więc być może również był nadaniem lennym $)^{71}$. Obowiązek płacenia podymnego przez kmieci w wysokości 2 gr. rocznie należy do sfery podatkowej i nie ma związku z formą dzierżenia ziemi. Obowiązek dotyczący świadczeń na rzecz zamków i umocnień wywodzi się z prawa ruskiego, choć podobne świadczenie występowało też w prawie lennym. W prawie ruskim próżno szukać innych cech prawa lennego, jak ograniczenie dziedziczenia dóbr wyłącznie do linii męskiej.

Autor, godząc obydwie koncepcje, utożsamia pomistia z tezy Liwancjewa $z$ ruskim lennem według interpretacji Inkina i dodaje, że inaczej ta forma władania ziemią zwana jest ,wysługą”, którą błędnie utożsamia z nadaniem na prawie służebnym, czyli lennym. Kontynuując swe wywody, autor dowodzi, że różnice między votčina a „wysługą” (czyli prawem lennym, które nazywa również pomistia) zanikały $\mathrm{z}$ czasem, a szlachta w pierwszej połowie XVI w. doprowadziła zamiany „wysługi” na votčine, choć jak twierdzi, pozostały pewne różnice np. dziedziczenie tylko w linii męskiej w ,wysłudze” (s. 419) , $^{72}$. Wbrew swoim tezom, dwie strony dalej autor prezentuje inny podział własności na kategorie: votčina (własność dziedziczną), własność wysłużoną lub otrzymaną w dzierżawę oraz własność nabytą (kupioną). Po czym twierdzi, że „feudałowie będący właścicielami ziemi na prawie lennym” otrzymywali liczne przywileje z rąk królewskich, które umożliwiały im rozporządzanie swymi lennami (sprzedaż, dziedziczenie, zamiana, zastaw). Niestety, nie podał jednak żadnych przykładów tych przywilejów.

Te zawikłane wywody wymagają generalnej konstatacji, że wszelkie podobieństwa $\mathrm{w}$ formach władania ziemią na terenie Rusi, Polski czy krajów Europy Zachodniej były spowodowane rozwojem feudalnych stosunków społecznych, które wykształciły beneficjalny system władania ziemią. Jednak w różnych regionach Europy i na różnych etapach rozwoju, tych stosunków wykształcały się odmienne, charakterystyczne dla nich formy dzierżenia tych beneficjów. W Europie Zachodniej przyjęły one kształt prawa lennego, które samo w sobie cechowało się zróżnicowaniem regionalnym, w Czechach do końca XII w. istniała beneficjalna forma „wysługi”, na Rusi Moskiewskiej

${ }^{71}$ Bona Regalia Onerata in Terris Russiae etc. Lustratio 1469 r., [w:] Polska XVI wieku pod względem geograficzno-statystycznym. T. 7. Cz. 1.B. Ziemie ruskie. Ruś Czerwona, wyd. A. Jabłonowski, [w:] Źródła dziejowe, t. 18, Warszawa 1902, s. 18; AGAD, tzw. Metryka Litewska, sygn. IV. B. 9 (Księga wpisów przywilejów na dobra w województwie ruskim przedkładanych podczas „rewizji listów” w 1563/64 r.), k. 367v-368.

${ }^{72} \mathrm{~W}$ tej interpretacji uderza podobieństwo do procesu dążenia do zamiany prawa lennego na dziedziczne przez szlachtę ruską opisanego przez A. Prochaskę, Lenna i maństwa, s. 13-14, 22-26. 
wykształciły się pomjestja ${ }^{73}$, w Polsce w ustroju prawa książęcego jako ius militare (prawo rycerskie, w którym forma dzierżenia być może dość wcześnie uległa alodyzacji ${ }^{74}$ ), ale nie należy form tych przenosić do innych regionów, będących na innych etapach rozwoju stosunków społecznych i mających własną złożoną specyfikę.

Znacznie poprawniej przedstawiono w omawianej pracy stosunek władców do Cerkwi prawosławnej i Kościoła katolickiego na Rusi. Autor pozytywnie ocenia działania Kazimierza Wielkiego mające na celu odnowienie prawosławnej metropolii halickiej w 1370 r., dystansując się od niektórych tez historiografii, że były to działania pozorowane i kierowane cynicznym, osobistym interesem króla (s. 161). Jednakże wbrew opinii panującej w dawnej historiografii, zwłaszcza narodnickiej ${ }^{75}$, brak jest śladów źródłowych administracyjnej dyskryminacji prawosławnej Cerkwi (s. 163, 166). Jak dowodzi A. Janeczek, klauzule antyruskie w przywilejach lokacyjnych prawa niemieckiego, które rzekomo miały zabraniać nadawania prawa niemieckiego ludności ruskiej ze względu na jej religię, by zmuszać ją w ten sposób do przechodzenia na katolicyzm, w rzeczywistości miały wymiar osadniczy i gospodarczy. Chodziło tylko o to, by w nowo lokowanych osadach umieszczać ludność przybyłą z zewnątrz (bez względu na religię), aby zwiększyć zaludnienie, nie doprowadzając jednocześnie do rozkładu istniejącej struktury osadniczej $^{76}$. W konkluzji I. Bojko zresztą przyznaje, że działania te nie dążyły do całkowitej dyskryminacji i likwidacji Cerkwi (s. 163).

$\mathrm{Na}$ koniec warto jeszcze zwrócić uwagę na problem wzajemnego oddziaływania ruskiego i polskiego prawa zwyczajowego. W ostatnim rozdziale pracy autor porusza zagadnienie formowania się i funkcjonowania systemu prawnego Polski i jego wpływu na system prawny na Rusi Halickiej. Szczególnie zaś podkreśla wpływ Prawdy Ruskiej zarówno na prawo zwyczajowe, jak i stanowione w Polsce. Porównując przepisy prawne zaczerpnięte z prawdy ruskiej z zapisami z najstarszego zwodu prawa polskiego (Księgi Elbląskiej), autor dochodzi do wniosku, że polskie prawo zwyczajowe w ogromnej mierze czerpało ze wzorów ruskich, tym bardziej że ruskie zostało skodyfikowane ponad dwa wieki przed pierwszymi próbami spisania prawa polskiego.

${ }^{73}$ A. Kijas, System pomiestny, s. 7 i n.; M. Handelsman, Z metodyki badań feodalizmu. Podstawy porównania, „Themis Polska. Pismo nauce prawa poświęcone”. Ser. II, t. 7: 1917, s. 15, 64-65; S. Russocki, Z badań nad czeskim systemem beneficjalnym, s. 33-45; idem, Spory o istotę i geneze feudalizmu europejskiego, „Kwartalnik Historyczny”, t. 78: 1971, s. 409, 412.

${ }^{74}$ K. Modzelewski, Organizacja gospodarcza, s. 206-227; K. Buczek, Prawo rycerskie, s. 157-169; S. Gawlas, O kształt zjednoczonego Królestwa, s. 81-82, 86-88; J. Wroniszewski, Król jako właściciel ziemski w średniowiecznej Polsce, [w:] Król w Polsce XIV i XV wieku, red. A. Marzec i M. Wilamowski, Kraków 2006, s. 104-115; T. Jurek, Geneza szlachty polskiej, [w:] Šlechta, moc a reprezentace ve stredoveku. Colloquia mediaevalia Pragensia 9, Praha 2007, s. 81-99.

${ }^{75}$ М. Грушевський, Історія України-Руси, Т. V, s. 228, 232, Т. VI, s. 139.

${ }^{76}$ A. Janeczek, Exceptis schismaticis, s. 527-541. 
Ma to świadczyć również o różnicy w poziomie rozwoju obydwu systemów prawnych. Tę samą konkluzję autor formułuje po porównaniu przepisów prawnych w statutach Kazimierza Wielkiego z Prawdą Ruską. Stwierdza on bowiem, że królowie polscy, zwłaszcza Kazimierz Wielki, stanowiąc prawo, wzorowali się na wyżej rozwiniętym prawie ruskim (s. 353, 362, 367-369). Abstrahując od meritum, wypada podkreślić, że autor używa argumentu wyższości prawa ruskiego nad polskim, uzasadniając przyczyny, dla których Kazimierz Wielki po zajęciu Rusi Halickiej nie ingerował w jej ustrój i system prawny. Ten brak ingerencji autor tłumaczy faktem, iż polskie prawo stało na niższym poziomie, wobec tego nie mogło stać się fundamentem reform prawa na Rusi. Natomiast kodyfikacja prawa przez Kazimierza Wielkiego była spowodowana faktem, iż w granicach Królestwa znalazł się region o wyższym stopniu rozwoju prawnego, dlatego król zmuszony był zreformować system prawny całego państwa, dostosowując go do wyższych wzorców pochodzących z Rusi Halickiej.

Wiele zagadnień zawartych w książce I. Bojki wymaga krytycznej oceny. Kilka tu podjętych unaocznia zarówno wielowątkowość, jak i - niestety - warsztatowe niedostatki omawianej rozprawy. Polemikę utrudnia to, że nie zawsze wiadomo, jakie autor ma poglądy, ponieważ jedynie przytacza myśli poszczególnych badaczy, nawet sprzeczne ze sobą, jednak pozostawia je bez komentarza. Owszem - prawem, a nawet obowiązkiem autora jest prezentacja różnych teorii, ale w sposób przemyślany i wedle klarownej koncepcji. W omawianej pracy wyraźnie brakuje takiego uporządkowania.

Praca w żaden sposób nie zamyka problemu badawczego, wręcz przeciwnie - uwypukla ogromne luki i braki w naszej dotychczasowej wiedzy na ten temat oraz wskazuje nie tylko na potrzebę dalszych badań, prowadzenia dyskusji nad ich metodologią, ale też konieczność ściślejszej polsko-ukraińskiej współpracy naukowej. 
